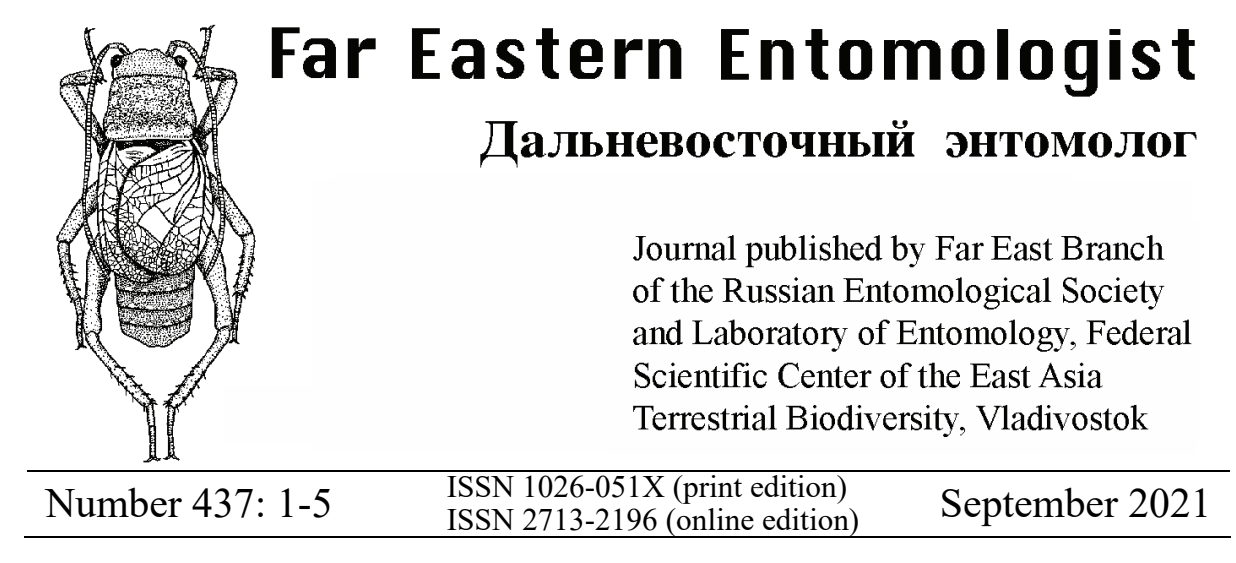

https://doi.org/10.25221/fee.437.1

http://zoobank.org/References/F5BAB989-0D79-40EA-9807-E761BE95998B

\title{
DISCOVERY OF THE GENUS ODONTOMYRME LELEJ, 1983 (HYMENOPTERA: MUTILLIDAE) IN NEW GUINEA WITH DESCRIPTION OF A NEW SPECIES
}

\begin{abstract}
A. S. Lelej
Federal Scientific Center of the East Asia Terrestrial Biodiversity, Far East Branch of the Russian Academy of Sciences, Vladivostok, 690022, Russia.E-mail: lelej@biosoil.ru

Summary. Odontomyrme rasnitsyni sp. n. is described and illustrated from Papua New Guinea. A new species is similar to O. addenda (André, 1901) from Australia (Queensland) but differs by small apicomedial yellowish cuticular spot on metasomal tergum 2 and tergum 3 with black cuticula. The genus Odontomyrme Lelej, 1983 is newly recorded from New Guinea Island.

Key words: Hymenoptera, Mutillidae, velvet ant, taxonomy, new species.

А. С. Лелей. Нахождение рода Odontomyrme Lelej, 1983 (Hymenoptera: Mutillidae) в Новой Гвинее с описанием нового вида // Дальневосточный энтомолог. 2021. N 437. C. 1-5.

Резюме. Из Папуа Новой Гвинеи описан Odontomyrme rasnitsyni sp. n. Новый вид сходен с O. addenda (André, 1901) из Австралии (Квинсленд), но отличается небольшим срединновершинным желтоватым пятном на втором метасомальном тергите и черной кутикулой третьего тергита. Род Odontomyrme Lelej, 1983 впервые указывается для острова Новая Гвинея.
\end{abstract}

\section{INTRODUCTION}

Mutillid wasps of the Australasian Region are a poorly studied component of the insect fauna. Currently, there are more than 260 Australian species described and 
placed in 13 genera: Odontomutilla Ashmead, 1899 (4 species), Trogaspidia Ashmead, 1899 (5), and Wallacidia Lelej \& Brothers, 2008 (2) in the subfamily Mutillinae; Ancistrotilla Brothers, 2012 (12), Aglaotilla Brothers, 2018 (14), Ascetotilla Brothers, 1971 (8), Australotilla Lelej, 1983 (5), Bothriomutilla Ashmead, 1899 (3), Ephutomorpha André, 1902 (186), Eurymutilla Ashmead, 1899 (11), Odontomyrme Lelej, 1983 (6), and Ponerotilla Brothers, 1994 (4) in the subfamily Sphaeropthalminae; Orientilla Lelej, 1979 (1) in the subfamily Dasylabrinae, and Mutillidae incertae sedis - 4 species (Brothers et al., 2012, Brothers \& Lelej, 2017; Pagliano et al., 2020). Ephutomorpha represents a portmanteau genus used to house all Australasian sphaeropthalmine species pending their revision, and thus contains a wide morphological diversity (Brothers, 2018).

Recently Sk. Yamane gave me mutillid female collected in Papua New Guinea from the genus Odontomyrme. This specimen is described and illustrated here as a new species and the genus Odontomyrme is newly recorded from New Guinea. Holotype of new species is deposited in the Federal Scientific Center of the East Asia Terrestrial Biodiversity Vladivostok, Russia (IBSS).

The following abbreviations are used: S1, S2, S3, etc., to denote the first, second, third, etc. metasomal sterna; T1, T2, T3, etc., to denote the first, second, third, etc. metasomal terga.

\section{TAXONOMY}

\section{Genus Odontomyrme Lelej, 1983}

Odontomyrme Lelej, 1983: 613, of; Brothers \& Lelej, 2017: 59, 94, 우 ô; Brothers et al., 2019: 582, 우 ô; Pagliano et al., 2020: 75, fig. 103, ㅇ․

Type-species Odontomyrme tobiasi Lelej, 1983 (female), by original designation. The male of the type species has not been recognized; the presumed males of the other species were associated by Brothers \& Lelej (2017) based on the specimens collected in copula.

DIIAGNOSIS (based on Brothers \& Lelej, 2017). FEMALE. Head rounded, narrower than mesonotum. Eyes oval, moderately convex with distinct ommatidia. Antennal scrobe with sinuate dorsal carina almost reaching eye. Antenna dorsally broadened medially; flagellomere 1 shorter or slightly longer than pedicel, other flagellomeres shorter than their width. Mesosoma with protruding mesopleuron; mesonotum considerably wider than propodeum. Humeral and propodeal angles usually toothed; scutellar scale lacking. Metasoma sub-cylindrical, segment 1 slightly narrower than second one; T1 with differentiated anterior and dorsal surfaces; T2 long, laterally weakly arcuate, basolaterally with felt line. Pygidial area developed. MALE. Scape with two equally well developed ventral ridges; pedicel about as long as wide and about as long as flagellomere 1. Pro-mesonotal suture abruptly Vshaped (laterally straight, mesally angled). Tegula slightly elongate, posteriorly reaching trans-scutal articulation or slightly beyond; T1 gradually broadened posteriorly, more or equal $0.5 \times$ length $\mathrm{T} 2$, apically constricted from T2; lateral felt line on $\mathrm{S} 2$ distinct but minute. 
SPECIES INCLUDED AND DISTRIBUTION. Includes six Australian species and two subspecies: O. tobiasi Lelej, 1983; O. gilberti (André, 1898), O. difficilis (André, 1901), O. abjecta (André, 1901), O. addenda addenda (André, 1901), O. addenda ferrugineipes (André, 1903), O. addenda rufocincta (André, 1903), and $O$. sessilis (André, 1901). One new species from New Guinea described below.

REMARKS. Originally the genus Odontomyrme Lelej, 1983 was described in the tribe Odontomutillini Lelej, 1983 of the subfamily Dasylabrinae Invrea, 1964; later (Lelej \& Nemkov, 1997) this tribe was placed in the subfamily Ephutinae Ashmead, 1903 but in last classification (Brothers \& Lelej, 2017) Odontomyrme is placed in the tribe Dasymutillini Brothers et Lelej, 2017 of the subfamily Sphaeropthalminae Schuster, 1949. This genus is required the revision because real number of the species is much more, some of them are still undescribed, another ones are included in the unrevised Australian genus Ephutomorpha André, 1902.

Odontomyrme rasnitsyni Lelej, sp. n.

http://zoobank.org/NomenclaturalActs/AE231BC1-6881-4B02-AE30-6E9435EA7759

Figs $1-5$

TYPE MATERIAL. Holotype - + , Papua New Guinea: Gumi, 2.II 2004, leg. S. Onoda [IBSS].

DIAGNOSIS. FEMALE. Genal carina well developed forming on hypostomal carina tubercle. Scutellar scale lacking. Mesopleuron convex, mesonotum wider than pronotum or propodeum, mesopleural vertical carina well developed with long white sub-erect setae. Metasoma black, T2 with apicomedial small yellowish cuticular spot, T6 with elongate pygidium, with lateral carina oblitered apically, with sparse striae ( $\sim 15$ at midpoint), no striae reaching posterior margin, apical quarter smooth shiny.

DESCRIPTION. FEMALE. Body length $4.2 \mathrm{~mm}$. Coloration and setation. Head black, mandible except apex brownish-red, flagellomeres ventrally yellowishbrown. Mesosoma black with brownish-red legs. Metasoma black, T2 with apicomedial small yellowish cuticular spot, T6 brownish-red. Sparse fully plumose white setae on clypeus, face below antennal scrobe, vertex, pronotum anterad, posterior propodeal face, T1 anterior face, T2-6 laterally, S2-6. Sub-erect sparse grayish setae on frons, gena, scape. Flagellomeres with dense recumbent microsetae. Mesosoma dorsally with sparse mixed black and grayish sub-erect setae. Legs with rather dense recumbent and sub-erect white setae. T1 dorsally with black sub-erect setae whitish on posterior border. T2 with sparse sub-erect black setae, longer denser yellowish ones posteriorly. T3-5 with same setae as on T2 posteriorly.

Head. Antennal tubercles connected by weak transverse carina. Antennal scrobe with sinuate dorsal carina almost reaching eye. Ratio pedicel and flagellomeres 1-3 20:25:25:30. Genal carina well developed forming on hypostomal carina tubercle. Mandible inner border with one preapical denticle. Scape bicarinate ventrally. Clypeus with arcuate subapical transverse carina. Frons, vertex and gena punctures dense. 
Mesosoma. Mesopleuron convex, mesonotum wider than pronotum or propodeum, mesopleural vertical carina well developed with long white sub-erect setae. Posterior propodeal face reticulate with some interspaces reduced, forming apparent striae and tubercles. Lateral and posterior propodeal faces separated by wavy subdentate carina. Mesopleuron, metapleuron and propodeal lateral face mostly smooth. Dorsum of mesosoma with dense punctures, larger and confluent on disc.

Metasoma. T2 basolaterally with short felt line. S1 with simple longitudinal carina. Lateral process of T1 (dorsal view) rectangle. T1 posterior border smooth shiny. T6 with elongate pygidium, with lateral carina oblitered apically, with sparse striae ( $\sim 15$ at midpoint), no striae reaching posterior margin, apical quarter smooth shiny.
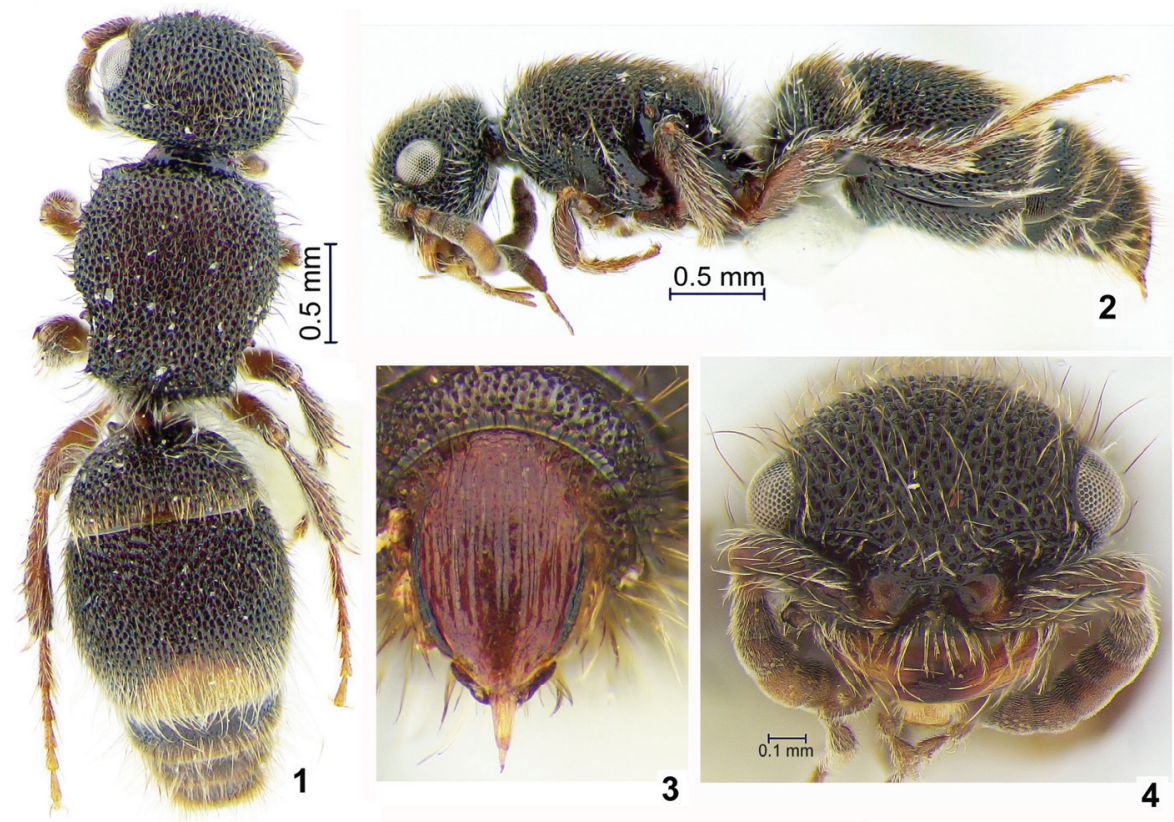

Figs 1-4. Odontomyrme rasnitsyni sp. n., holotype; 1 - habitus, dorsal view, 2 - habitus, lateral view, 3 - pygidial plate, 4 - head, face view.

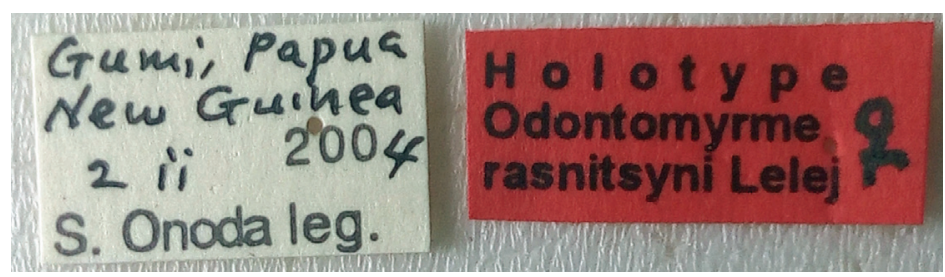

Fig. 5. Odontomyrme rasnitsyni sp. n., labels of holotype. 


\section{MALE unknown.}

REMARKS. In Lelej's (1983) key, this species keys to Odontomyrme addenda (André, 1901), which is known from Australia (Queensland) and has small apicomedial yellowish cuticular spot on T2, T3 with black cuticula (large apicomedial reddish cuticular spot on T2, T3 with reddish cuticula in addenda).

ETYMOLOGY. The specific name is dedicated to Alexandr Pavlovich Rasnitsyn, world authority on Hymenoptera classification and evolution, for his 85 years jubilee. Treat as a noun in genetive.

\section{ACKNOWLEDGMENTS}

Valery Loktionov helped me with the photos of new species. Many thanks S. Onoda, who collected the holotype and Sk. Yamane who made this specimen available for this study.

\section{REFERENCES}

André, E. 1898. Contribution a la connaissance des Mutillides de l'Australia. Mémoires de la Société Zoologique de France, 11: 256-308.

André, E. 1901. Nouvelle contribution a la connaissance des Mutillides de l'Australia. Mémoires de la Société Zoologique de France, 14: 467-513.

André, E. 1903. Quatrième contribution à la connaissance des Mutillides de l'Australie. Mémoires de la Société Zoologique de France, 15: 240-278.

Brothers, D.J. 2018. Aglaotilla, a new genus of Australian Mutillidae (Hymenoptera) with metallic coloration. Zootaxa, 4415(2): 357-368. DOI: https://doi.org/10.11646/zootaxa. 4415.2.6

Brothers, D.J. \& Lelej, A.S. 2017. Phylogeny and higher classification of Mutillidae (Hymenoptera) based on morphological reanalyses. Journal of Hymenoptera Research, 60: 197. DOI: https://doi.org/10.3897/jhr.60.20091

Brothers, D.J., Lelej, A.S. \& Williams, K.A. 2019. Genus-group names of Mutillidae (Hymenoptera): corrections and updates since 2008. Zootaxa, 4651 (3): 578-588. DOI: https://doi.org/10.11646/zootaxa.4651.3.10.

Brothers, D.J., Stringer, D.N., Jennings, J.T. \& Austin, A.D. 2012. Australian Faunal Directory: Family Mutillidae. Australian Biological Resources Study. Available from: https://biodiversity.org.au/afd/taxa/MUTILLIDAE (accessed 18 January 2018)

Lelej, A.S. 1983. On the velvet ants (Hymenoptera, Mutillidae) of Australia. Entomologicheskoe Obozrenie, 62 (3); 612-619. [In Russian; English translation: Entomological Review, 1984, 62 (3); 152-160].

Lelej, A.S. \& Nemkov, P.G. 1997. Phylogeny, evolution and classification of Mutillidae (Hymenoptera). Far Eastern Entomologist, 46: 1-24.

Pagliano, G., Brothers, D.J., Cambra, R., Lelej, A.S., Lo Cascio, P., Matteini Palmerini, M., Scaramozzino, P.L., Williams, K.A. \& Romano, M. 2020. Checklist of names in Mutillidae (Hymenoptera), with illustrations of selected species. Bollettino del Museo Regionale di Scienze Naturali di Torino, 36(1-2): 5-425. 